\title{
Russulfoen, a new cytotoxic marasmane sesquiterpene from Russula foetens
}

\author{
Ki Hyun Kim ${ }^{1}$, Hyung Jun Noh${ }^{1}$, Sang Un Choi ${ }^{2}$, Ki Moon Park ${ }^{3}$, Soon-Ja Seok ${ }^{4}$ and Kang Ro Lee ${ }^{1}$
}

The Journal of Antibiotics (2010) 63, 575-577; doi:10.1038/ja.2010.84; published online 7 July 2010

Keywords: cytotoxicity; marasmane sesquiterpene; Russula foetens; Russulaceae; russulfoen

The genus Russula is one of the largest in Agaricales and contains more than 100 species in forests worldwide. The family Russulaceae (subdivision Basidiomycotina) are important symbionts, forming mycorrhiza with higher plants and trees. The fungal subdivision Basidiomycotina produces many toxic sesquiterpenes derived from the protoilludane skeleton, which is transformed and rearranged to various sesquiterpenes, including marasmane sesquiterpenes, ${ }^{1}$ which were discovered more than 50 years ago $^{2}$ and have antibacterial, antifungal, cytotoxic and phytotoxic activities. ${ }^{3,4}$ Although a number of Lactarius species have been studied with regard to their secondary metabolites, marasmane sesquiterpenes, particularly, ${ }^{1}$ the Russula mushrooms have been rarely investigated, despite the large number of species. Therefore, as a part of a systematic study of Korean poisonous mushrooms, ${ }^{5,6}$ we investigated the constituents of the fruiting bodies of the mushroom $R$. foetens, widely distributed throughout Korea and other East Asian countries. This is a poisonous mushroom that contains gastrointestinal irritants and several marasmane sesquiterpenes. ${ }^{7,8}$ Column chromatographic separation of its $\mathrm{MeOH}$ extract resulted in the isolation of a new marasmane sesquiterpene lactone named russulfoen (1), together with two known marasmane sesquiterpene lactones, $7 \alpha, 8 \alpha, 13$-trihydroxy-marasm5-oic acid $\gamma$-lactone $(2)^{9}$ and $8 \alpha, 13$-dihydroxy-marasm-5-oic acid $\gamma$-lactone $(3),{ }^{8}$ one known ergosterol, $(22 E, 24 R)-5 \alpha, 8 \alpha$-epidioxyergosta-6,22-dien-3 $\beta$-ol $(4),{ }^{10}$ as well as $(1 R, 2 R)$-1-phenylpropane-1, 2 -diol $(5)^{11}$ that was isolated from the natural source for the first time (Figure 1). Their structures were elucidated on the basis of spectroscopic studies, including 2D-NMR experiments. In this study, we describe the isolation and structural elucidation of 1 and the cytotoxic activities of compounds 1-5.

The air-dried and powdered fruiting bodies of $R$. foetens $(7.2 \mathrm{~g})$ were extracted with $80 \% \mathrm{MeOH}$ two times at room temperature and filtered. The filtrate was evaporated under vacuum to afford a methanolic extract (1.3 g), which was suspended in $\mathrm{H}_{2} \mathrm{O}$, and then partitioned with $n$-hexane, $\mathrm{CHCl}_{3}$ and $n$ - $\mathrm{BuOH}$, successively, yielding $n$-hexane (90 mg), $\mathrm{CHCl}_{3}(120 \mathrm{mg})$ and $n$ - $\mathrm{BuOH}$ fractions $(150 \mathrm{mg})$. Each fraction was evaluated for cytotoxicity against A549, SK-OV-3, SK-MEL-2 and HCT-15 cell lines using the sulforhodamine B assay. It was found that the $n$-hexane and $\mathrm{CHCl}_{3}$ soluble fractions were of moderate cytotoxicity against the tumor cell lines. The $n$-hexane soluble fraction $(90 \mathrm{mg}$ ) was separated on a Sephadex LH-20 (Pharmacia, Uppsala, Sweden) column with $\mathrm{CH}_{2} \mathrm{Cl}_{2}-\mathrm{MeOH}$ (1:1) as the eluent to give three fractions $(\mathrm{H} 1-\mathrm{H} 3)$. Fraction $\mathrm{H} 2$ (12 mg) was further purified by normal-phase preparative HPLC using a solvent of $n$-hexane-EtOAc (1:1) at a flow rate of $2.0 \mathrm{ml} \mathrm{min}^{-1}$ (Apollo Silica $5 \mu \mathrm{m}$ column (Alltech, Nicholasville, KY, USA), $250 \times 10 \mathrm{~mm}$ ) to give compound $4(5 \mathrm{mg})$. The $\mathrm{CHCl}_{3}$ soluble fraction $(120 \mathrm{mg})$ was separated on a Sephadex LH-20 column with $\mathrm{CH}_{2} \mathrm{Cl}_{2}-\mathrm{MeOH}$ (1:1) as the eluent to give two fractions (C1-C2). Fraction C2 (25 mg) was further purified by $\mathrm{RP}^{-\mathrm{C}_{18}}$ preparative HPLC (Econosil RP-18 $10 \mu$ column (Alltech), $250 \times 10 \mathrm{~mm} ; 60 \% \mathrm{MeOH}$ ) to afford compounds 2 $(3 \mathrm{mg})$ and $5(3 \mathrm{mg})$. The $n$ - $\mathrm{BuOH}$ soluble fraction $(150 \mathrm{mg})$ showing weak cytotoxicity was also separated on a Sephadex LH-20 column with $\mathrm{CH}_{2} \mathrm{Cl}_{2}-\mathrm{MeOH}$ (1:1) as the eluent to give four fractions (B1-B4). Fraction $\mathrm{B} 3(30 \mathrm{mg})$ was further purified by $\mathrm{RP}-\mathrm{C}_{18}$ preparative HPLC (Econosil RP-18 $10 \mu$ column, $250 \times 10 \mathrm{~mm} ; 60 \% \mathrm{MeOH}$ ) to give compounds 1 ( $4 \mathrm{mg}$ ) and $3(3 \mathrm{mg})$.

Compound 1 was obtained as a colorless oil. Its molecular formula was determined to be $\mathrm{C}_{15} \mathrm{H}_{22} \mathrm{O}_{4}$ from the $[\mathrm{M}+\mathrm{H}]^{+}$peak at $m / z$ 267.1590 (calcd. for $\mathrm{C}_{15} \mathrm{H}_{23} \mathrm{O}_{4}, 267.1596$ ) in the positive-ion highresolution FAB-MS spectrum. The IR spectrum of 1 showed a broad hydroxyl band at $3388 \mathrm{~cm}^{-1}$ and a $\gamma$-lactone carbonyl absorption at $1751 \mathrm{~cm}^{-1}$. Its UV spectrum revealed end absorption $\lambda_{\max } 217 \mathrm{~nm}$ with low extinction. The physico-chemical properties of 1 are summarized in Supplementary Information. The ${ }^{1} \mathrm{H}$ - and ${ }^{13} \mathrm{C}-\mathrm{NMR}$ spectral data of $\mathbf{1}$ are shown in Table 1.

The ${ }^{1} \mathrm{H}-\mathrm{NMR}$ spectrum (Table 1 ) of $\mathbf{1}$ displayed signals for the presence of two methyl groups at $\delta_{\mathrm{H}} 1.28$ and 1.05 (each $3 \mathrm{H}, \mathrm{s}$ ), two oxygenated methylene groups at $\delta_{\mathrm{H}} 4.45(1 \mathrm{H}, \mathrm{t}, J=10.0 \mathrm{~Hz}), 4.08(1 \mathrm{H}, \mathrm{dd}$,

\footnotetext{
${ }^{1}$ Natural Products Laboratory, School of Pharmacy, Sungkyunkwan University, Suwon, Korea; ²Bio-organic Science Division, Pharmacology Research Center, Korea Research Institute of Chemical Technology, Teajeon, Korea; ${ }^{3}$ Department of Food Science and Biotechnology, Sungkyunkwan University, Suwon, Korea and ${ }^{4}$ Division of Applied Microbiology, RDA, National Institute of Agricultural Science and Technology, Suwon, Korea Correspondence: Prof Dr KR Lee, Natural Products Laboratory, School of Pharmacy, Sungkyunkwan University, 300 Chonchon-dong, Jangan-ku, Suwon 440-746, Korea. E-mail: krlee@skku.ac.kr

Received 21 April 2010; revised 31 May 2010; accepted 13 June 2010; published online 7 July 2010
} 

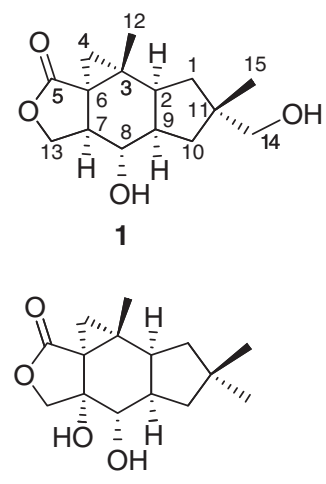

2

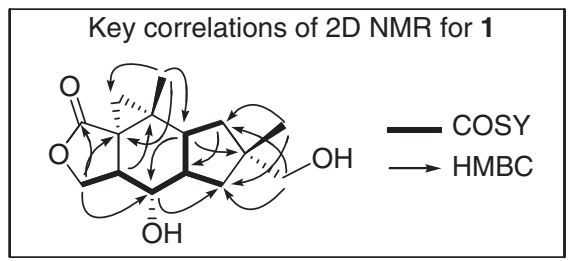<smiles>CC(O)[C@H](O)c1ccccc1</smiles>

5

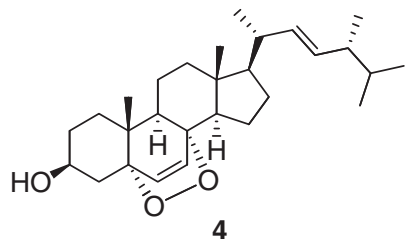

Figure 1 Structures of compounds $\mathbf{1 - 5 .}$

Table $1{ }^{1} \mathrm{H}$ - and ${ }^{13} \mathrm{C}$-NMR data of 1 and 3

\begin{tabular}{|c|c|c|c|c|c|}
\hline \multirow[b]{2}{*}{ Position } & \multicolumn{3}{|c|}{1} & \multicolumn{2}{|r|}{3} \\
\hline & $\delta_{C}$ & $\delta_{H}$ & $H M B C$ & $\delta_{C}$ & $\delta_{H}$ \\
\hline $1 \beta$ & & $1.31(1 \mathrm{H}, \mathrm{dd}, 14.0,12.0)$ & & & $1.47(1 \mathrm{H}, \mathrm{dd}, 14.0,13.4)$ \\
\hline 2 & 44.8 & $2.62(1 \mathrm{H}, \mathrm{m})$ & $\mathrm{C}-4,6,8,10,11,12$ & 45.2 & $2.63(1 \mathrm{H}, 13.4,6.8,6.7)$ \\
\hline 3 & 27.8 & & & 28.4 & \\
\hline 5 & 177.7 & & & 177.9 & \\
\hline 6 & 29.5 & & & 29.5 & \\
\hline 7 & 43.0 & $2.33(1 \mathrm{H}, \mathrm{ddd}, 10.0,9.5,7.0)$ & $C-3,4,5,9$ & 43.8 & $2.40(1 \mathrm{H}, \mathrm{ddd}, 9.9,9.3,7.3)$ \\
\hline 8 & 73.3 & $3.25(1 \mathrm{H}, \mathrm{dd}, 11.0,9.5)$ & $\mathrm{C}-2,6,10,13$ & 73.6 & $3.27(1 \mathrm{H}, \mathrm{dd}, 10.2,9.9)$ \\
\hline 9 & 44.1 & $1.51(1 \mathrm{H}, \mathrm{m})$ & $C-1,3,7,11$ & 44.8 & $1.59(1 \mathrm{H}, \mathrm{m})$ \\
\hline $10 \alpha$ & 38.1 & $1.64(1 \mathrm{H}, \mathrm{dd}, 14.0,2.0)$ & $\mathrm{C}-1,2,8,14,15$ & 44.7 & $1.66(1 \mathrm{H}, \mathrm{dd}, 14.3,1.0)$ \\
\hline $13 \beta$ & & $4.08(1 \mathrm{H}, \mathrm{dd}, 10.0,7.0)$ & & & $4.18(1 \mathrm{H}, \mathrm{dd}, 9.3,7.3)$ \\
\hline $14 \alpha$ & 70.8 & $3.46(1 \mathrm{H}, \mathrm{d}, 12.0)$ & $C-1,10,15$ & 31.8 & $1.26(3 \mathrm{H}, \mathrm{s})$ \\
\hline $14 \beta$ & & $3.43(1 \mathrm{H}, \mathrm{d}, 12.0)$ & & & \\
\hline 15 & 26.0 & $1.05(3 \mathrm{H}, \mathrm{s})$ & $C-1,10,14$ & 32.4 & $1.05(3 \mathrm{H}, \mathrm{s})$ \\
\hline
\end{tabular}

NMR data were obtained in $500 \mathrm{MHz}$ for ${ }^{1} \mathrm{H}$ and $125 \mathrm{MHz}$ for ${ }^{13} \mathrm{C}$ in $\mathrm{CD}_{3} \mathrm{OD}$, and values in parentheses are coupling constants in $\mathrm{Hz}$.

$J=10.0,7.0 \mathrm{~Hz})$, and $3.46(1 \mathrm{H}, \mathrm{d}, J=12.0 \mathrm{~Hz}), 3.43(1 \mathrm{H}, \mathrm{d}, J=12.0 \mathrm{~Hz})$, and an oxygenated methine group at $\delta_{\mathrm{H}} 3.25(1 \mathrm{H}, \mathrm{dd}, J=11.0$, $9.5 \mathrm{~Hz}$ ). Analysis of ${ }^{1} \mathrm{H}$ - and ${ }^{13} \mathrm{C}-\mathrm{NMR}$ spectra together with HSQC indicated that 15 carbon signals were composed of a carbonyl carbon, two methyl carbons, five methylene carbons (including two oxygenated methylene carbons), four methine carbons (including one oxygenated methine carbon) and three quaternary carbons. The presence of the signals of $\mathrm{H}-4$ at $\delta_{\mathrm{H}} 1.28(1 \mathrm{H}, \mathrm{d}, J=4.5 \mathrm{~Hz}, \mathrm{H}-4 \alpha)$ and $0.90(1 \mathrm{H}, \mathrm{d}, J=4.5 \mathrm{~Hz}, \mathrm{H}-4 \beta)$ together with 15 carbon signals of 1 allowed us to assign the marasmane skeleton to compound $\mathbf{1}$, because the ${ }^{1} \mathrm{H}-\mathrm{NMR}$ spectrum of marasmane sesquiterpene shows two $\mathrm{H}-4$ protons as a doublet with a characteristic coupling constant of $J=\sim 5 \mathrm{~Hz} .{ }^{8,9}$ The ${ }^{1} \mathrm{H}$ - and ${ }^{13} \mathrm{C}-\mathrm{NMR}$ resonances of 1 were similar to those of $3,{ }^{8}$ except for the presence of additional signals $\left(\delta_{\mathrm{H}} 3.46\right.$ and 3.43) assignable to the oxygenated methylene group (Table 1$)$. The signals assignable to $\mathrm{C}-1\left(\delta_{\mathrm{C}} 37.5\right), \mathrm{C}-14\left(\delta_{\mathrm{C}} 70.8\right)$ and C-15 $\left(\delta_{\mathrm{C}} 26.0\right)$ were present in ${ }^{13} \mathrm{C}-\mathrm{NMR}$ spectrum of $\mathbf{1}$ instead of the corresponding signals for C-1 $\left(\delta_{\mathrm{C}} 41.8\right), \mathrm{C}-14\left(\delta_{\mathrm{C}} 31.8\right)$ and C-15 $\left(\delta_{\mathrm{C}} 32.4\right)$ of 3 , which supported the presence of the oxygenated methylene group of C-14. The structure of 1 was confirmed by analysis of the ${ }^{1} \mathrm{H}-{ }^{1} \mathrm{H}$ COSY, HSQC and HMBC spectroscopic data (Table 1, Figure 1).

The coupling constant $(J=11.0 \mathrm{~Hz})$ for $\mathrm{H}-8$ and $\mathrm{H}-9$ suggested that they exist as trans form. ${ }^{9}$ The absolute configurations of 1 were established on the basis of the convenient Mosher ester procedure in combination with NOESY experiment. ${ }^{12}$ Esterification of 1 yielded diastereoisomeric $\alpha$-methoxy- $\alpha$-trifluoromethylphenylacetate (MTPA) diesters, bis[(S)-MTPA $]$ ester (1s) and bis[(R)-MTPA] ester (1r). Diagnostic ${ }^{1} \mathrm{H}$-NMR chemical shift differences between the MTPA esters of $\mathbf{1}$ $\left[\Delta \delta=\delta_{S}-\delta_{R}\right.$ ] (Figure 2) revealed the absolute configuration at C-8 to be $S$. This suggested that $\mathrm{H}-8$ has the $\beta$-orientation. The cross peaks between $\mathrm{H}-8$ and $\mathrm{H}_{3}-12$, between $\mathrm{H}-8$ and $\mathrm{H}_{3}-15$, between $\mathrm{H}-7$ and $\mathrm{H}-9$, between $\mathrm{H}-4$ and $\mathrm{H}-7$, between $\mathrm{H}-2$ and $\mathrm{H}-9$, between $\mathrm{H}-2$ and 
a
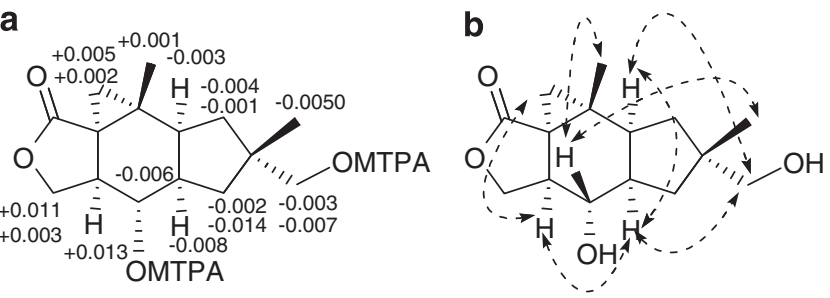

Figure $2 \Delta \delta$ Values $\left(\delta_{S}-\delta_{R}\right)$ in p.p.m. of the two $\alpha$-methoxy- $\alpha$ trifluoromethylphenylacetate (MTPA) esters derived from 1 (a) and Key NOESY correlations of $\mathbf{1}$ (b).

Table 2 Cytotoxic activities of compounds (1-5) isolated from R. foetens

\begin{tabular}{lrrrr}
\hline & \multicolumn{4}{c}{$I C_{50}(\mu \mathrm{m})$} \\
\cline { 2 - 5 } Compound & A549 & SK-OV-3 & SK-MEL-2 & HCT-15 \\
\hline 1 & 23.0 & 28.2 & 15.4 & $>30.0$ \\
2 & 25.7 & $>30.0$ & $>30.0$ & 20.9 \\
3 & 29.4 & 28.7 & 22.5 & $>30.0$ \\
4 & 19.5 & 18.4 & 17.8 & 19.9 \\
5 & $>30.0$ & $>30.0$ & 23.5 & $>30.0$ \\
Doxorubicin & 0.021 & 0.003 & 0.012 & 0.038
\end{tabular}

$\mathrm{IC}_{50}$ value of compounds against each cancer cell line, which was defined as the concentration $(\mu \mathrm{M})$ that caused $50 \%$ inhibition of cell growth in vitro.

$\mathrm{H}-14$, and between $\mathrm{H}-9$ and $\mathrm{H}-14$ in the NOESY spectrum suggested that the cyclopropane ring at $\mathrm{C}-3 / 6$ takes the $\alpha$-orientation and the oxygenated methylene group of $\mathrm{C}$ - 14 also takes the $\alpha$-orientation (Figure 2). Thus, the structure of $\mathbf{1}$ was established as $8 \alpha, 13,14$-trihydroxymarasm-5-oic acid $\gamma$-lactone and the compound was named russulfoen.

Cytotoxic activities of the isolated compounds (1-5) were evaluated against the A549, SK-OV-3, SK-MEL-2 and HCT-15 human tumor cell lines in vitro using the sulforhodamine $\mathrm{B}$ assay. ${ }^{13}$ The marasmane sesquiterpenes (1-3) exhibited moderate cytotoxicity against the A549, SK-OV-3, SK-MEL-2 and HCT-15 cell lines (Table 2). Compound 4 also exhibited moderate cytotoxicity against the four human tumor cell lines.

\section{ACKNOWLEDGEMENTS}

We thank Drs EJ Bang, SG Kim and JJ Seo at the Korea Basic Science Institute for the NMR and MS spectra measurements. This research was supported by Basic Science Research Program through the National Research Foundation of Korea (NRF) funded by the Ministry of Education, Science and Technology (2010-0007162).

1 Abraham, W. R. Bioactive sesquiterpenes produced by fungi: are they useful for humans as well? Cur. Med. Chem. 8, 583-606 (2001).

2 Kavanagh, F., Hervey, A. \& Robbins, W. J. Antibiotic substances from Basidiomycetes; Marasmius conigenus. Proc. Natl. Acad. Sci. USA 35, 343-349 (1949).

3 Dugan, J. J., De Mayo, P., Nisbet, M., Robinson, J. R. \& Anchel, M. Terpenoids. XIV. The constitution and biogenesis of marasmic acid. J. Am. Chem. Soc. 88, 2838-2844 (1966).

4 Anke, H., Hillen-Maske, E. \& Steglich, W. Antibiotics from basidiomycetes. XXX. $9 \beta$-Hydroxymarasmic acid and other sesquiterpenoids from submerged cultures of a basidiomycete. Z. Naturforsch. 44c, 1-6 (1989).

5 Kim, K. H., Park, K. M., Choi, S. U. \& Lee, K. R. Macrolepiotin, a new indole alkaloid from Macrolepiota neomastoidea. J. Antibiot. 62, 335-338 (2009).

6 Kim, K. H., Choi, S. U., Park, K. M., Seok, S. J. \& Lee, K. R. Cytotoxic constituents of Amanita subjunquillea. Arch. Pharm. Res. 31, 579-586 (2008).

7 Wang, X. N. et al. A new marasmane sesquiterpene from the basidiomycete Russula foetens. Z. Naturforsch. 60b, 1065-1067 (2005).

8 Wang, X. N., Shen, J. H., Du, J. C. \& Liu, J. K. Marasmane sesquiterpenes isolated from Russula foetens. J. Antibiot. 59, 669-672 (2006).

9 Daniewski, W. M. et al. Marasmane lactones from Lactarius vellereus. Phytochemistry 31, 913-915 (1992).

$10 \mathrm{Xu}, \mathrm{M}$. L. et al. Cytotoxic constituents isolated from the fruit bodies of Hypsizigus marmoreus. Arch. Pharm. Res. 30, 28-33 (2007).

11 Trudeau, S ., Morgan, J. B., Shrestha, M . \& Morken, J. P. Rh-catalyzed enantioselective diboration of simple alkenes: Reaction development and substrate scope. J. Org. Chem. 70, 9538-9544 (2005).

12 Su, B. N. et al. New chemical constituents of Euphorbia quinquecostata and absolute configuration assignment by a convenient Mosher ester procedure carried out in NMR tubes. J. Nat. Prod. 65, 1278-1282 (2002).

13 Skehan, P. et al. New colorimetric cytotoxicity assay for anticancer-drug screening. J. Natl. Cancer Inst. 82, 1107-1112 (1990).

Supplementary Information accompanies the paper on The Journal of Antibiotics website (http://www.nature.com/ja) 